TITLE:

\title{
Synthesis of sterically hindered phthalocyanines and their applications to dye-sensitized solar cells
}

\section{AUTHOR(S):}

Eu, Seunghun; Katoh, Takashi; Umeyama,

Tomokazu; Matano, Yoshihiro; Imahori, Hiroshi

\section{CITATION:}

Eu, Seunghun ...[et al]. Synthesis of sterically hindered phthalocyanines and their applications to dye-sensitized solar cells. Dalton Transactions 2008, 2008(40): 5476-5483

\section{ISSUE DATE:}

2008-10-28

URL:

http://hdl.handle.net/2433/89509

\section{RIGHT:}

Copyright (C) 2008 Royal Society of Chemistry. Seunghun Eu, Takashi Katoh, Tomokazu Umeyama, Yoshihiro Matano and Hiroshi Imahori, Dalton Transactions, 2008(40), 2008, 5476-5483. http://dx.doi.org/10.1039/b803272f - Reproduced by permission of The Royal Society of Chemistry; This is not the published version. Please cite only the published version.; この論文は出版社版でありません。引用の際には出版社版をご磼認ご利用ください。 


\section{Synthesis of Sterically Hindered Phthalocyanines and Their Applications to Dye-Sensitized Solar Cells}

Seunghun Eu, ${ }^{a}$ Takashi Katoh, ${ }^{b}$ Tomokazu Umeyama, ${ }^{a}$ Yoshihiro Matano, ${ }^{a}$ and Hiroshi $\operatorname{Imahori}^{* a, c, d}$

${ }^{a}$ Department of Molecular Engineering, Graduate School of Engineering, Kyoto University, Nishikyo-ku, Kyoto 615-8510, Japan

${ }^{b}$ Goi Research Center, Chisso Petrochemical Corporation, 5-1 Goikaigan, Ichihara, Chiba 290-8551, Japan

${ }^{c}$ Institute for Integrated Cell-Material Sciences (iCeMS), Kyoto University, Nishikyo-ku, Kyoto 615-8510, Japan

${ }^{d}$ Fukui Institute for Fundamental Chemistry, Kyoto University, 34-4, Takano-Nishihiraki-cho, Sakyo-ku, Kyoto 606-8103, Japan

E-mail: imahori@scl.kyoto-u.ac.jp 


\section{Summary}

Phthalocyanines with high peripheral substitutions and free from potential contamination by regioisomers have been synthesized and evaluated as photosensitizers for dye-sensitized solar cell applications. Each of the sterically hindered precursor compounds was accomplished by the Suzuki-Miyaura cross-coupling reactions with the arylchloride and corresponding boronic acids. Metal free phthalocyanine-sensitized solar cell showed no photocurrent generation due to its low excited singlet state (LUMO) compared with the conduction band of the $\mathrm{TiO}_{2}$. Upon zinc metalation, the LUMO level of the phthalocyanine was pushed up, and this variation afforded the exergonic free energy change for the electron injection. The zinc phthalocyanine-sensitized solar cell displayed $0.57 \%$ of power conversion efficiency $(\eta)$ and $4.9 \%$ of maximal IPCE in the near infrared region. More importantly, the cell prepared with and without the presence of chenodeoxycholic acid revealed no difference in the power conversion efficiency. This implies that the well-known aggregation tendency of phthalocyanines that is considered to enhance the self-quenching of the phthalocyanine excited singlet state is effectively suppressed by the high degree of substitutions. Significance of the driving force for the electron injection and the distance between the dye core and the $\mathrm{TiO}_{2}$ surface is also highlighted for devising high performance phthalocyanine photosensitizers. 


\section{Introduction}

Exhaustion of the fossil fuels and the global energy concerns have never been recognized as seriously as recent days. In this context, research activities to acquire energy from the sun, as a clean and inexhaustible resource, are being extensively exploited. $^{1}$ After the seminal report of Grätzel et al, ${ }^{2}$ dye-sensitized solar cells (DSSCs) with mesoporous $\mathrm{TiO}_{2}$ have been regarded as one of the most promising candidates among a variety of regenerative energy sources developed to date. The fundamental aspects of the DSSCs have been well documented based on the widespread research efforts to disclose the nature of the devices including interfacial photoinduced electron transfer, role of mesoporous semiconductor electrode, and electrolyte. ${ }^{3}$ From the practical and industrial point of view, however, the improvement in the performance has been rather stagnated during the last two decades. The main reason for this would be attributed to the limited light-harvesting capabilities of the existing dyes, especially for the near-infrared region. ${ }^{4}$ As such, to devise and develop novel photosensitizer dyes that can effectively harvest the red light is the urgent task to make the DSSCs practically viable.

Phathalocyanines are the proper choice for this objective due to their strong Q band light absorption properties at around $700 \mathrm{~nm} .^{5} \quad$ Their extreme stabilities against thermal, chemical, and photochemical reactions are definitively the desirable features for the long-term and outdoor robustness for the DSSCs. Applications of phthalocyanines for DSSCs as photosensitizers, however, have not been successful. ${ }^{6}$ Notoriously poor solubility to common organic solvents and high tendency of 
aggregations have been attributed to the main reason for impeding to reveal their potentials for DSSCs. Recent study by Torres et al. demonstrated the usefulness of phthalocyanines for red light-harvesting provided that the degree of aggregation is partially diminished by introducing three bulky $t$-butyl groups into the macrocycle plane. ${ }^{7}$ The directionality in the excited state of the dye was also emphasized as an important factor for efficient light-harvesting. However, the reported compound is the mixture of the regioisomers, and this may result in the formation of rather complex monolayer on the $\mathrm{TiO}_{2}$ surface, making it difficult to disclose the relationship between the monolayer structure and the photovoltaic properties. More importantly, the cell performance is still aided with the co-adsorption of chenodeoxycholic acid which is well-known to suppress the dye aggregation on the $\mathrm{TiO}_{2}$ surface. Although the power conversion efficiency is the highest among the reported phthalocyanine-sensitized $\mathrm{TiO}_{2}$ cell $(\eta=3.5 \%)$, it is much lower than those of Ru dye-based DSSCs $(\eta=10-11 \%) .^{2-4}$ Therefore, further studies are still needed to elucidate the close relationship between the molecular structure and the photovoltaic properties toward the improvement of cell performances.

Herein we report the synthesis and photovoltaic properties of a novel highly substituted zinc phthalocyanine carboxylic acid $(\mathrm{ZnPc})$ and its metal free counterpart $\left(\mathrm{H}_{2} \mathrm{Pc}\right)$ as depicted in Figure 1. The compounds retain sterically hindered eight phenyl groups where the neighboring phenyl rings are rotated each other with respect to the phthalocyanine plane to avoid the steric congestion around the ortho-protons. Moreover, the six phenyl groups also possess bulky $t$-butyl moieties. Therefore, ZnPc 
and $\mathrm{H}_{2} \mathrm{Pc}$ are expected to show high solubility toward common organic solvents and the reduced tendency of aggregation. Since the two neighboring $\beta$ positions are occupied by the same functional groups, the target compound can be isolated free from the problem of regioisomeric mixtures. Two carboxylic acid binding groups could guarantee the stable immobilization of the phthalocyanine onto the $\mathrm{TiO}_{2}$ surface. Additionally, intramolecular push-pull character afforded by electron-donating ( $t$-butyl) and electron-withdrawing (carboxylic acid) groups would be anticipated to make the efficient electron transfer from the phthalocyanine excited singlet state to the conduction band (CB) of the $\mathrm{TiO}_{2}$.

Figure 1

\section{Results and Discussion}

Synthesis Syntheses of phthalocyanines used in this study were achieved by the statistical condensation method. ${ }^{8}$ A key step in this protocol is the preparation of the adequate phthalonitrile precursors. Synthetic routes to $\mathrm{H}_{2} \mathrm{Pc}$ and $\mathrm{ZnPc}$ are displayed in Scheme 1. Precursor compound $\mathbf{1}$ was accomplished by the Suzuki-Miyaura cross-coupling reaction between the 4,5-dichlorophthalonitrile and 4-t-butylphenylboronic acid. The Suzuki-Miyaura coupling is one of the most widely used reactions for C-C bond formation. ${ }^{9} \quad$ However, it is well known that the coupling reactions for the substrates with high steric hindrance or for the arylchlorides are ineffective, as for the substrate in this study. To attain the desired compound, we have 
employed electron-rich and sterically hindered ligand, 2-(2',6'-dimethoxybiphenyl)dicyclohexylphosphine (S-Phos). ${ }^{10}$

\section{SCHEME 1}

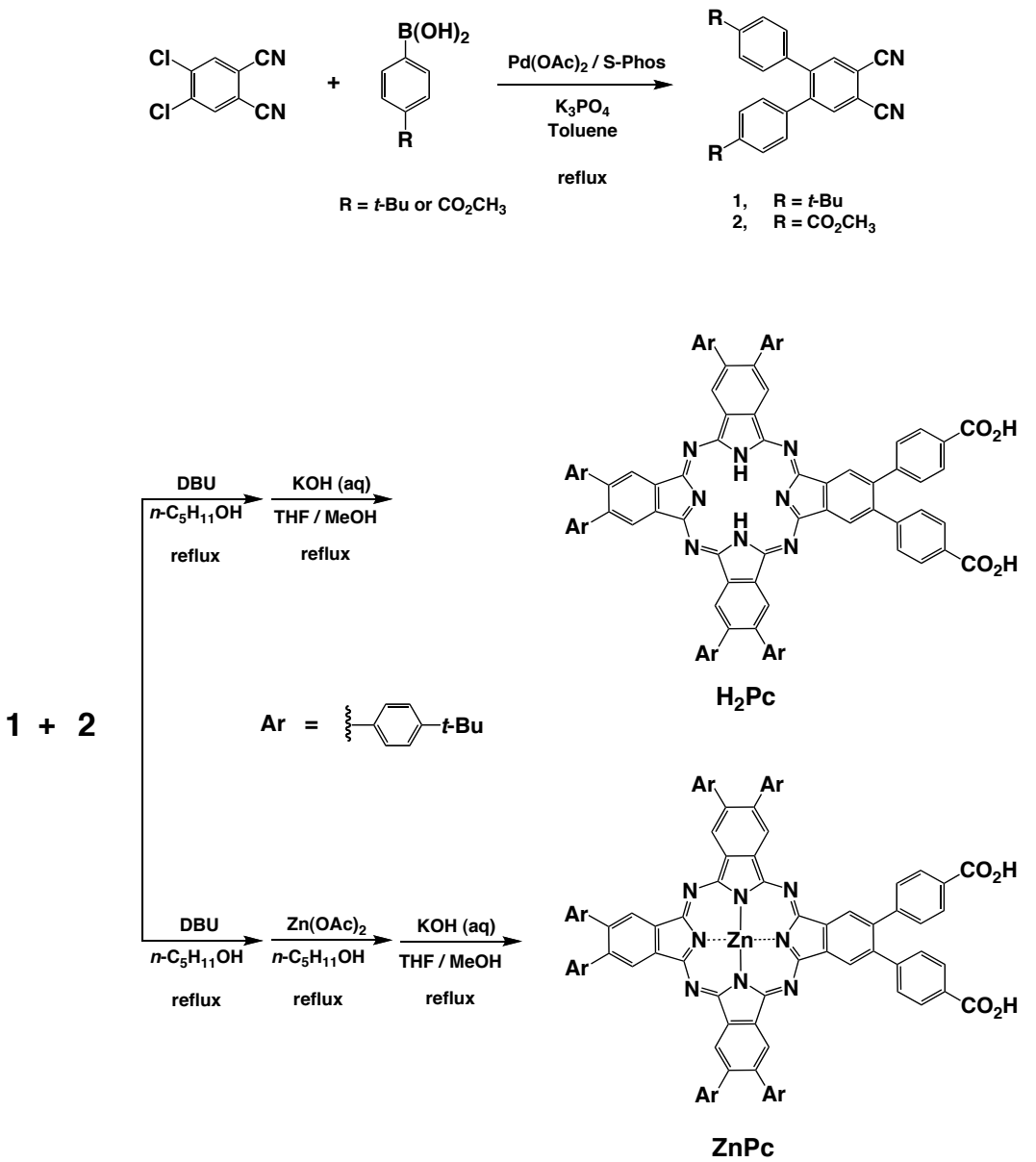

Because the electron-rich ligand with high steric hindrance such as S-Phos or $\mathrm{P}(t-\mathrm{Bu})_{3}$ makes the palladium $(0)$ coordinatively unsaturated, the cross-coupling reactions even for the difficult substrates proceeded smoothly with moderate to good yield. ${ }^{11}$ Precursor compound $\mathbf{2}$ was also achieved through the Suzuki-Miyaura cross-coupling between 4,5-dichlorophthalonitrile and 4-(methoxycarbonylphenyl)boronic acid, but it needed longer reaction time compared with that of $\mathbf{1}$. Owing to the presence of ester group, the boronic acid would be an inferior nucleophile compared with 
4-t-butylphenylboronic acid, and it could be the reason of the longer reaction time.

After obtaining the precursor compounds, we have tried to prepare the desired cyclotetramer by statistical condensation of $\mathbf{1}$ and $\mathbf{2}$ in 1-pentanol in the presence of DBU. Although we have expected to obtain 2,3,9,10,16,17-hexakis(4-t-butylphenyl)23,24-bis(4-methoxycarbonylphenyl)phthalocyanine, we have reached a result to get the mixture of two phthalocyanine compounds. The compounds showed two molecular ion peaks at 1630.7 and 1686.8 with the intensity ratio of $1: 3$ on the mass spectrometry (MALDI-TOF). Each of the peaks corresponds to 2,3,9,10,16,17-hexakis(4-t-butylphenyl)-23-(4-methoxycarbonylphenyl)-24-(4-pentoxycarbonylphenyl)phthalocyanine, and $\quad 2,3,9,10,16,17$-hexakis(4-t-butylphenyl)-23,24-bis(4-pentoxycarbonylphenyl)phthalocyanine, respectively. We believed that the exchange reaction between the acetate and pentanoate was occurred during the cyclo-condensation reaction, as is already reported. ${ }^{6(\mathrm{~g}),(\mathrm{h})}$ Because both of the compounds would afford the same target compound (i.e., $\mathrm{H}_{2} \mathrm{Pc}$ ) by hydrolysis, the mixture was directly employed for the next reaction without further purification. The basic hydrolysis of the compounds in THF/methanol containing aqueous potassium hydroxide solution afforded the corresponding phthalocyanine carboxylic acid, $\mathrm{H}_{2} \mathrm{Pc}$. To achieve the zinc phthalocyanine carboxylic acid $(\mathrm{ZnPc})$, zinc (II) was inserted into the core of the phthalocyanine esters beforehand by the treatment of zinc acetate. The resulting compounds displayed the molecular ion peaks at 1692.5 and 1748.6 on the mass spectrometry (MALDI-TOF). Each of the peaks corresponds to 2,3,9,10,16,17-hexakis(4-t-butylphenyl)-23-(4-methoxycarbonylphenyl)-24-(4- 
pentoxycarbonylphenyl)phthalocyanatozinc

(II) and 2,3,9,10,16,17-hexakis-

(4-t-butylphenyl)-23,24-bis(4-pentoxycarbonylphenyl)phthalocyanatozinc

(II),

respectively. The basic hydrolysis of the compounds in THF/methanol containing aqueous potassium hydroxide solution afforded the corresponding zinc phthalocyanine carboxylic acid, ZnPc. Structures of all the new compounds were verified by spectroscopic analyses including ${ }^{1} \mathrm{H}$ NMR, ${ }^{13} \mathrm{C}$ NMR, FT-IR, mass spectra, and elemental analyses.

Optical and Electrochemical Properties UV-visible absorption spectra for $\mathrm{H}_{2} \mathrm{PC}$ and $\mathrm{ZnPc}$ in $\mathrm{THF}$ are displayed in Figure 2. Each of the compounds showed the characteristic optical feature of the zinc and metal free phthalocyanine, respectively. The peak positions at B and Q bands regions are summarized in Table 1. The steady state fluorescence spectra of the phthalocyanines were also measured in THF and the wavelengths for emission maxima are listed in Table 1. The Stokes shifts are determined to be $68.2 \mathrm{~cm}^{-1}$ for $\mathrm{H}_{2} \mathrm{Pc}$ and $165.6 \mathrm{~cm}^{-1}$ for $\mathrm{ZnPc}$. This fairly small value suggests that the variations in the atomic coordinates during the electronic transitions are small for both of the compounds. From the intersection of the normalized absorption and emission spectra, the zero-zero excitation energies $\left(E_{0-0}\right)$ are determined to be $1.73 \mathrm{eV}$ for $\mathrm{H}_{2} \mathrm{Pc}$ and $1.78 \mathrm{eV}$ for $\mathrm{ZnPc}$ in $\mathrm{THF}^{12}$ 
Figure 2 and TABLE 1

To determine the first oxidation potential $\left(E_{\mathrm{ox}}\right)$ of the phthalocyanines, differential pulse voltammetry (DPV) ${ }^{13}$ measurements were performed in DMF containing $0.1 \mathrm{M}$ tetrabutylammonium hexafluorophosphate (TBAP) as a supporting electrolyte and the results are summarized in Table 1. Both $\mathrm{H}_{2} \mathrm{Pc}$ and $\mathrm{ZnPc}$ display one oxidation peak corresponding to the phthalocyanine radical cation under the same sweep conditions $\left(-0.1 \mathrm{~V}\right.$ to $+0.8 \mathrm{~V}$ vs $\left.\mathrm{Ag} / \mathrm{AgNO}_{3}\right)$. The oxidation potential of $\mathrm{H}_{2} \mathrm{Pc}$ appears at $+1.27 \mathrm{~V}$ (vs NHE), whereas that of $\mathrm{ZnPc}$ is determined to be $+0.94 \mathrm{~V}$ (vs NHE). It indicates that the phthalocyanine is easier to be oxidized upon zinc (II) metalation, as reported for the other phthalocyanine compound. ${ }^{14}$ This variation results in the important consequence for the electron injection from the excited state dye (LUMO) to the $\mathrm{CB}$ of the $\mathrm{TiO}_{2}$ (vide infra). On the basis of the spectroscopic and electrochemical measurements, driving forces for electron injection from the LUMO of the dye to the CB of the $\mathrm{TiO}_{2}\left(-0.5 \mathrm{~V}\right.$ vs NHE) $\left(\Delta G_{\mathrm{inj}}\right)^{15}$ and the regeneration of the dye 
radical cation by $\mathrm{I}^{-} / \mathrm{I}_{3}^{-}$redox couple $\left(+0.5 \mathrm{~V}\right.$ vs NHE) $\left(\Delta G_{\mathrm{reg}}\right)^{15}$ for the phthalocyanine-sensitized solar cells are evaluated (Table 1). Both of the processes for ZnPc-sensitized $\mathrm{TiO}_{2}$ cell are thermodynamically feasible, whereas the electron injection from the excited $\mathrm{H}_{2} \mathrm{Pc}$ to the $\mathrm{CB}$ of the $\mathrm{TiO}_{2}$ is thermodynamically uphill.

DFT Calculations DFT calculations were employed to gain insight into the equilibrium geometry and electronic structures for the molecular orbitals of the phthalocyanines. The calculated structures do not show negative frequencies, implying that the optimized geometries are in the global energy minima. ${ }^{16}$ Figure 3 illustrates the electron density distributions of $\mathrm{H}_{2} \mathrm{Pc}$ and $\mathrm{ZnPc}$ in their respective LUMOs. Sufficient electron densities around the carboxylic acid binding group on the LUMO of dye are required for the good electronic coupling between the excited state of dye and $3 \mathrm{~d}$ orbital of $\mathrm{TiO}_{2} \cdot{ }^{17} \quad$ Apart from our expectations, there exists electron density distribution near carboxylic acid binding groups neither of the phthalocyanines.

Figure 3 


\section{Photovoltaic and Photoelectrochemical Properties of Phthalocyanine-Sensitized}

TiO 2 Cells Mesoporous $\mathrm{TiO}_{2}$ films (10- $\mu$ m-thick) were prepared from colloidal suspension of $\mathrm{TiO}_{2}$ nanoparticles (P25) (see Experimental Section). The $\mathrm{TiO}_{2}$ electrodes were immersed into THF containing $0.05 \mathrm{mM}$ phthalocyanine at room temperature to give the phthalocyanine-modified $\mathrm{TiO}_{2}$ electrodes. Since the light-harvesting ability and consequently the cell performance are, to a large extent, controlled by the surface coverage $(\Gamma)$ of the dye on the $\mathrm{TiO}_{2}$ surface, first we examined the immersing time dependency of the $\Gamma$ value for the phthalocyanines. Both of the dyes showed similar and rather slow adsorption rates, and reached saturated coverage $(\Gamma)$ on the surface for about $10 \mathrm{~h}$ of immersing time (Figure 4). Total amounts of the dyes adsorbed on the $\mathrm{TiO}_{2}$ surface were determined by measuring the changes in the absorbance of the dye solutions before and after immersing the $\mathrm{TiO}_{2}$ films. Dye concentrations on the $\mathrm{TiO}_{2}$ films $\left(0.25 \mathrm{~cm}^{2}\right.$ of area with thickness of $\left.10 \mu \mathrm{m}\right)$ are determined to be about $1.4 \times 10^{-10} \mathrm{~mol} \mathrm{~cm}^{-2}$. Assuming that (i) the phthalocyanine molecule is a rectangular hexahedron and (ii) the phthalocyanine molecules are densely packed onto the $\mathrm{TiO}_{2}$ surface with a perpendicular orientation, the occupied area of one 
molecule on the $\mathrm{TiO}_{2}$ surface is calculated to be ca. $103 \AA^{2}\left(4.3 \times 24.0 \AA^{2}\right)$. Accordingly, the $\Gamma$ value is estimated to be $1.6 \times 10^{-10} \mathrm{~mol} \mathrm{~cm}$, which is close to the experimental value. The $\mathrm{TiO}_{2}$ electrodes modified with $\mathrm{H}_{2} \mathrm{Pc}$ and $\mathrm{ZnPc}$ are denoted as $\mathrm{TiO}_{2} / \mathrm{H}_{2} \mathrm{Pc}$ and $\mathrm{TiO}_{2} / \mathrm{ZnPc}$, respectively.

Figure 4

To judge the potential of $\mathrm{H}_{2} \mathrm{Pc}$ and $\mathrm{ZnPc}$ as a photosensitizer for DSSC, we evaluated their cell performances using $\mathrm{P} 25 \mathrm{TiO}_{2}$ film. A $10-\mu$ m-thick $\mathrm{TiO}_{2}$ electrode was modified with $\mathrm{H}_{2} \mathrm{Pc}(0.05 \mathrm{mM})$ which was dissolved in THF for the immersing time of 1-72 h. The $\mathrm{H}_{2} \mathrm{Pc}$-sensitized $\mathrm{TiO}_{2}$ cell showed no power conversion due to the lower energy level of the $\mathrm{H}_{2} \mathrm{Pc}$ excited singlet state ( $-0.46 \mathrm{~V}$ vs NHE) than that of the CB of the $\mathrm{TiO}_{2}\left(-0.5 \mathrm{~V}\right.$ vs NHE). ${ }^{15}$ In contrast, the $\eta$ values of the $\mathrm{ZnPc}$-sensitized cell gradually increased with increasing the immersing time to reach maximum $\eta$ values $\left(\eta_{\max }\right)$ of ca. $0.6 \%$ for $12 \mathrm{~h}$. The power conversion efficiency $(\eta)$ is derived from the equation: $\eta=J_{\mathrm{SC}} \times V_{\mathrm{OC}} \times f f$, where $J_{\mathrm{SC}}$ is the short circuit current, $V_{\mathrm{OC}}$ is the open 
circuit potential, and $f f$ is the fill factor. Further increase of the immersing time of up to $72 \mathrm{~h}$ exhibited no noticeable changes in the $\eta$ values. The time profiles of the $\eta$ values (Figure 5) correlate well with those of the $\Gamma$ values (vide supra). This is in sharp contrast with the porphyrin-sensitized $\mathrm{TiO}_{2}$ cells in which at first the $\eta$ values are increased and then decreased significantly with increasing the immersing time. ${ }^{4 b, 18}$ The representative photocurrent-voltage characteristics of $\mathrm{ZnPc}$-sensitized $\mathrm{TiO}_{2}$ cells with the immersing time of $12 \mathrm{~h}$ is depicted in Figure $6 ; \eta=0.57 \pm 0.03 \%$ with $J_{\mathrm{SC}}=1.47 \pm$ $0.05 \mathrm{~mA} \mathrm{~cm}^{-2}, V_{\mathrm{OC}}=0.54 \pm 0.02 \mathrm{~V}$, and $f f=0.71 \pm 0.03$

Figures 5 and 6

For phthalocyanine-sensitized $\mathrm{TiO}_{2}$ cell, co-adsorbates such as chenodeoxycholic acid have been employed to reduce the tendency of dye aggregations on the $\mathrm{TiO}_{2}$ surface. ${ }^{6,7}$ For instance, previous report by Sundström et al. materialized the double enhanced performance by introducing the co-adsorbates into the immersing bath $(\eta=0.29 \%$ in the absence of the co-adsorbates and $\eta=0.54 \%$ in the presence of the co-adsorbates). ${ }^{19}$ To 
further improve the performance of the present cell, we also introduced the chenodeoxychloic acid $(2.5 \mathrm{mM})$ to the $\mathrm{ZnPc}$-THF solution $(0.05 \mathrm{mM})$, and prepared the phthalocyanine-sensitized $\mathrm{TiO}_{2}$ cell. The cell, however, exhibited no apparent difference in the $\eta$ values with the cell prepared in the absence of chenodeoxycholic acid under the same conditions (Figure 7); $\eta=0.54 \pm 0.03 \%, J_{\mathrm{sc}}=1.44 \pm 0.06 \mathrm{~mA} \mathrm{~cm}^{-2}$, $V_{\mathrm{oc}}=0.54 \pm 0.03 \mathrm{~V}$, and $f f=0.70 \pm 0.03$ for the cell with chenodeoxycholic acid. If there exist significant aggregations of $\mathrm{ZnPc}$ on the $\mathrm{TiO}_{2}$ surface, the electron injection yield would be considerably diminished by the accelerated decay of the $\mathrm{ZnPc}$ excited singlet state, leading to fair decrease in the cell performance, especially in the short circuit current. No apparent difference between the two cells with and without the presence of chenodeoxycholic acid reveals that the performance of our present cell is not perturbed by the well-known tendency of phthalocyanine aggregation. We understood this phenomenon is originated from the high steric hindrance of the ZnPc. Considering the degree of dye aggregation on the $\mathrm{TiO}_{2}$ surface is generally increased along with prolonged immersion, this interpretation is consistent with the parallel correlation between the time profiles of the $\eta$ values and the $\Gamma$ values (vide supra). 
Figure 7

To investigate the photovoltaic response of the present cell in more detail, we measured the photocurrent action spectra of $\mathrm{ZnPc}$-sensitized $\mathrm{TiO}_{2}$ cell under the same conditions for the photocurrent-voltage characteristic measurements (Figure 8a). ${ }^{20}$ To a large extent, the photocurrent response follows the general trend of the absorption feature of the $\mathrm{ZnPc} / \mathrm{TiO}_{2}$ (Figure $8 \mathrm{~b}$ ), indicating that the phthalocyanine is the main source for the photocurrent generation. The maximal IPCE value at the near-infrared region is measured to be $4.9 \%$.

Figure 8

Considering the full coverage on the $\mathrm{TiO}_{2}$ surface and the high molar extinction coefficient at around $700 \mathrm{~nm}$ region of $\mathrm{ZnPc}$, the low IPCE value of the $\mathrm{ZnPc}$-sensitized $\mathrm{TiO}_{2}$ cell cannot be explained by the light-harvesting efficiency. The remaining two 
factors are the quantum yield of electron injection from the $\mathrm{ZnPc}$ excited singlet state to the $\mathrm{CB}$ of the $\mathrm{TiO}_{2}$ electrode, and the efficiency of charge collection. ${ }^{21}$ The charge collection efficiency is determined primarily by the relative rate of charge transport and charge recombination. In DSSCs, the injected electron can be recombined by the resulting dye cation and $\mathrm{I}^{-} / \mathrm{I}_{3}{ }^{-}$redox couple before going to the outer circuit. ${ }^{22}$ The charge transport is reported to be occurred in the timescale of $10^{-7} \sim 10^{-5} \mathrm{~s}$, whereas the recombination between the electron and $\mathrm{I}^{-} / \mathrm{I}_{3}{ }^{-}$is happened in the timescale of $10^{-3} \sim 1 \mathrm{~s}$. 23,24 Although the time scale of the charge recombination with the resulting dye cation is known to be varied depending on the electron density on the $\mathrm{TiO}_{2}$, typical range is from $10^{-5}$ to $10^{-3} \mathrm{s.}^{23,25}$ Therefore, the charge collection efficiency may not be the limiting factor for the low photocurrent generation. The quantum yield of electron injection is controlled by the competing processes against electron injection such as intersystem crossing, nonradiative decay, emission, and excited-state quenching; the most important factor is, however, the driving force for electron injection $\left(\Delta G_{\text {inj }}\right)$ from the excited state dye to the $\mathrm{CB}$ of the $\mathrm{TiO}_{2} \cdot{ }^{3 \mathrm{c}}$ From the solution electrochemistry and spectroscopy, the $\Delta G_{\text {inj }}$ for $\mathrm{ZnPc}$-sensitized $\mathrm{TiO}_{2}$ cell is determined to be $-0.34 \mathrm{eV}$. 
Apparently, it indicates that the electron injection is thermodynamically feasible process.

The energy level of the $\mathrm{CB}$ is, however, not laid in the fixed point but is subject to change depending on the operating conditions of the DSSCs. Mesoporous $\mathrm{TiO}_{2}$ films have been known to show the Nernstian shifts in their CB level depending on the degree of surface protonations. ${ }^{26}$ The shift of the $\mathrm{CB}$ of about $0.3 \mathrm{eV}$ related with the changes in the electrolyte compositions is also reported..$^{22}$ Besides, the level of the CB would be raised in some degree due to the electron injection itself. The oxidation potential of dye, in addition, is to be positively shifted by the chemical adsorption on the $\mathrm{TiO}_{2}{ }^{18 c, 27}$ Thus, the actual driving force for the $\mathrm{ZnPc}$-sensitized cell is estimated to be smaller than the above-mentioned value. In such a case, the electron injection from the excited $\mathrm{ZnPc}$ to the $\mathrm{CB}$ of the $\mathrm{TiO}_{2}$ may be occurred mainly or only through surface states because there exist little available acceptor states for the efficient electron injection. ${ }^{28}$ Besides, the electronic coupling between the LUMO of the $\mathrm{ZnPc}$ and the $3 \mathrm{~d}$ orbital of the $\mathrm{TiO}_{2}$ cannot be anticipated to be large enough due to no apparent electron density on the carboxylic acid binding groups together with the intervening phenyl moieties between the $\mathrm{ZnPc}$ core and the carboxylic acid (vide supra). Thus, both of the small 
driving force and the weak electronic coupling would make the $\mathrm{ZnPc}$ an inefficient photosensitizer for DSSCs.

Certainly, the performance of our present cell is not good and this is far from our expectations. From this study, however, we can catch invaluable clue for devising effective phthalocyanine photosensitizers for DSSCs applications.

\section{Conclusions}

Sterically hindered zinc phthalocyanine carboxylic acid $(\mathrm{ZnPc})$ and its metal free counterpart $\left(\mathrm{H}_{2} \mathrm{Pc}\right)$ were synthesized and evaluated for the photosensitizer for DSSCs applications. The $\mathrm{H}_{2} \mathrm{Pc}$-sensitized $\mathrm{TiO}_{2}$ cell showed no photocurrent response due to its low excited singlet state compared with the $\mathrm{CB}$ of the $\mathrm{TiO}_{2}$. $\mathrm{ZnPc}$-sensitized $\mathrm{TiO}_{2}$ cell displayed $0.57 \%$ of power conversion efficiency $(\eta)$ and $4.9 \%$ of maximal IPCE value in the near-infrared region. Introduction of the chenodeoxycholic acid revealed no noticeable change in the cell performance, showing that the aggregation of $\mathrm{ZnPc}$ is effectively suppressed by the steric hindrance. The moderate cell performance can be rationalized by the small driving force for electron injection from the excited-state $\mathrm{ZnPc}$ 
to the $\mathrm{TiO}_{2}$, and the poor electronic coupling between the LUMO of the $\mathrm{ZnPc}$ and the

$\mathrm{CB}$ of the $\mathrm{TiO}_{2}$. Even though the performance of the present cell is not impressive, this study affords an important clue for devising novel phthalocyanines for DSSCs applications.

\section{Experimental}

\section{General}

All solvents and chemicals were of reagent grade quality, purchased, and used without further purification unless otherwise noted. Column chromatography and thin-layer chromatography (TLC) were performed with UltraPure Silica Gel (230-400 mesh, SiliCycle) and Silica gel $60 \quad \mathrm{~F}_{254}$ (Merck), respectively. ${ }^{1} \mathrm{H}$ NMR spectra were measured on a JEOL EX-400 (400 MHz) or a Varian Unity 500 (500 MHz) spectrometer. ${ }^{13} \mathrm{C}$ NMR spectra were measured on a JEOL EX-400 (100 MHz) spectrometer. High-resolution mass spectra (HRMS) were recorded on a JEOL JMS-HX 110A spectrometer (FAB) using 3-nitrobenzylic alcohol as a matrix or a JEOL JMS-700 MStatiom spectrometer (EI). Matrix assisted laser desorption/ionization time-of-flight (MALDI-TOF) mass spectra were made on a BRUKER Autoflex III using CHCA as a matrix. UV-vis absorption spectra were measured using a Perkin-Elmer Lambda 900 UV/vis/NIR Spectrometer. Steady-state fluorescence spectra were acquired by a SPEX Fluoromax-3 Spectrofluorometer. Spectroscopy 
grade tetrahydrofuran was used for the measurements of UV-visible absorption and fluorescence spectra. FT-IR spectra were acquired using by a JASCO FT/IR-470 plus or a FT/IR-4200 spectrometer with a $\mathrm{KBr}$ pellet. Melting points were recorded on a Yanagimoto micro-melting point apparatus and were not corrected.

Electrochemical measurements were made using a BAS 50W electrochemical workstation. Oxidation potentials in solution were determined by differential pulse voltammetry (DPV) with the pulse amplitude of $50 \mathrm{mV}$ in $\mathrm{Ar}$ saturated $N$, $N^{\prime}$-dimethylformamide containing $0.1 \mathrm{M}$ tetrabutylammonium perchlorate (TBAP) as a supporting electrolyte. A glassy carbon working electrode (3 $\mathrm{mm}$ diameter), $\mathrm{Ag} / \mathrm{AgNO}_{3}$ reference electrode, and $\mathrm{Pt}$ wire counter electrode were employed. Ferrocene/ferrocenium $(+0.642 \mathrm{~V}$ vs NHE) was used as an internal standard for all measurements. The measured potentials were quoted with reference to NHE.

\section{Synthesis}

4,5-Bis(4-t-butylphenyl)phthalonitrile (1). Although this compound is already reported, the previous characterization is not complete. ${ }^{29}$ A $100 \mathrm{~mL}$ of round-bottomed flask was charged with 4,5-dichlorophthalonitrile (1.87 g, $9.5 \mathrm{mmol})$, 4-t-butylphenylboronic acid (5.0 g, $28.1 \mathrm{mmol})$, palladium (II) acetate (44 mg, 0.2 
mmol), 2-(2',6'-dimethoxybiphenyl)dicyclohexylphosphine (200 mg, $0.49 \mathrm{mmol})$, $\mathrm{K}_{3} \mathrm{PO}_{4}(8.48 \mathrm{~g}, 40 \mathrm{mmol})$, and anhydrous toluene $(25 \mathrm{~mL})$. The solution was stirred at $90{ }^{\circ} \mathrm{C}$ for $2 \mathrm{~h}$. After cooling to room temperature, the reaction mixture was washed twice with water. The combined organic layers were washed once with water, subsequently dried over anhydrous magnesium sulfate, and then concentrated in vacuo. The residue was dissolved in hexane, and the solid material was obtained by precipitation. Dissolution in and reprecipitation with cold hexane was repeated until no solid material was appeared. Reprecipitation of the combined crude product with ethyl acetate/hexane afforded 1 as a needle-like off-white crystal (2.44 g, $6.22 \mathrm{mmol}$, $66 \%$ yield). Mp. 165.2-166.9 ${ }^{\circ} \mathrm{C} ;{ }^{1} \mathrm{H}$ NMR (400 MHz, $\left.\mathrm{CDCl}_{3}\right) \delta 7.82$ (s, 2H, phenyl H), $7.28(\mathrm{~d}, J=8.3 \mathrm{~Hz}, 4 \mathrm{H}$, phenyl H), $7.03(\mathrm{~d}, J=8.3 \mathrm{~Hz}, 4 \mathrm{H}$, phenyl H), $1.29(\mathrm{~s}, 18 \mathrm{H}$, $t$-butyl H); ${ }^{13} \mathrm{C} \mathrm{NMR}\left(100 \mathrm{MHz}, \mathrm{CDCl}_{3}\right)$ 151.77, 145.81, 135.54, 134.80, 129.01, 125.46, 115.56, 113.97, 34.64, 31.20; FT-IR (KBr) $v_{\max }$ 2964, 2905, 2869, 2233 (CN), $1735,1608,1589,1484,1462,1363,1268,1113,1015,915,835,594,569 \mathrm{~cm}^{-1}$; HRMS (EI positive) $m / z$ calcd for $392.2252\left(\mathrm{C}_{28} \mathrm{H}_{28} \mathrm{~N}_{2}\right)$, found 392.2249 ; Elemental analysis (\% calcd, \% found for $\left.\mathrm{C}_{28} \mathrm{H}_{28} \mathrm{~N}_{2}\right)$ : C (85.67, 85.37), H (7.19, 7.30), N (7.14, 6.87). 
4,5-Bis(4-methoxycarbonylphenyl)phthalonitrile (2). A $100 \mathrm{~mL}$ of round-bottomed flask was charged with 4,5-dichlorophthalonitrile $(1.0 \mathrm{~g}, 5.1 \mathrm{mmol})$, 4-(methoxycarbonylphenyl)boronic acid (2.7 g, $15.0 \mathrm{mmol})$, palladium (II) acetate (22 mg, $0.1 \mathrm{mmol}), 2-\left(2^{\prime}, 6\right.$ '-dimethoxybiphenyl)dicyclohexylphosphine (100 mg, 0.25 mmol), $\mathrm{K}_{3} \mathrm{PO}_{4}(4.24 \mathrm{~g}, 20 \mathrm{mmol})$, and anhydrous toluene $(20 \mathrm{~mL})$. The solution was stirred at $90{ }^{\circ} \mathrm{C}$ for $15 \mathrm{~h}$. After cooling to room temperature, the reaction mixture was washed twice with water. The combined organic layers were washed once with water, subsequently dried over anhydrous magnesium sulfate, and then concentrated in vacuo. Reprecipitation of the crude product from ethyl acetate twice afforded $\mathbf{2}$ as a plate-like off-white crystal (1.20 g, 2.62 mmol, $60.6 \%$ yield). Mp. 225.6-227.1 ${ }^{\circ} \mathrm{C} ;{ }^{1} \mathrm{H}$ NMR (300 MHz, $\left.\mathrm{CDCl}_{3}\right) \delta 7.96$ (d, J=8.4 Hz, 4H, phenyl H), 7.89 (s, 2H, phenyl H), 7.17 (d, $J=8.4 \mathrm{~Hz}, 4 \mathrm{H}$, phenyl H), 3.92 (s, 6H, ester $\mathrm{H}) ;{ }^{13} \mathrm{C} \mathrm{NMR}\left(75 \mathrm{MHz}, \mathrm{CDCl}_{3}\right)$ 166.20, 144.86, 141.58, 135.39, 130.50, 130.00, 129.39, 115.31, 114.97, 52.38; FT-IR (KBr) $v_{\max } 3437,2236(\mathrm{CN}), 1725,1609,1436,1314,1282,1188,1115,1105,1018,861,777$, 713, $523 \mathrm{~cm}^{-1}$; HRMS (EI positive) $\mathrm{m} / z$ calcd for $396.1110\left(\mathrm{C}_{26} \mathrm{H}_{16} \mathrm{~N}_{2} \mathrm{O}_{4}\right)$, found 396.1114; Elemental analysis (\% calcd, \% found for $\left.\mathrm{C}_{26} \mathrm{H}_{16} \mathrm{~N}_{2} \mathrm{O}_{4}\right)$ : C $(72.72,72.79), \mathrm{H}$ 
(4.07, 4.05), O (16.14, 16.29), N (7.07, 6.87).

\section{2,3,9,10,16,17-Hexakis(4-t-butylphenyl)-23,24-bis(4-carboxyphenyl)phthalocyanine}

$\left(\mathbf{H}_{2} \mathbf{P c}\right)$. A $200 \mathrm{~mL}$ of round-bottomed flask was charged with 1 (4.24 g, $\left.10.8 \mathrm{mmol}\right), 2$

(1.43 g, $3.60 \mathrm{mmol}), 1,8$-diazabicyclo[5.4.0]undec-7-ene (DBU) (0.3 g, $1.97 \mathrm{mmol})$, and 1-pentanol $(60 \mathrm{~mL})$. The solution was stirred at reflux for $20 \mathrm{~h}$ and cooled to room temperature. The solvent was then removed under reduced pressure. The solid material was obtained from methanol, and subjected to silica gel column chromatography (chloroform/hexane $=3: 1$ ). The second fraction was collected and reprecipitated from methanol. Silica gel column chromatography (chloroform/hexane $=1: 5)$ of the previously collected material afforded a dark green solid (1.02 g). The solid showed two molecular ion peaks at 1630.7 and 1686.8 with the intensity ratio of 1:3 on the mass spectrometry (MALDI-TOF). Each of the peaks corresponds to 2,3,9,10,16,17-hexakis(4-t-butylphenyl)-23-(4-methoxycarbonylphenyl)-24-(4pentoxycarbonylphenyl)phthalocyanine, and 2,3,9,10,16,17-hexakis(4-t-butylphenyl)23,24-bis(4-pentoxycarbonylphenyl)phthalocyanine, respectively. The mixture was directly employed for the next reaction without further purification. 
To a solution of the previously collected dark green solid $(1.03 \mathrm{~g})$ in $\mathrm{THF} / \mathrm{methanol}(2: 1(\mathrm{v} / \mathrm{v}), 280 \mathrm{~mL})$ in a $500 \mathrm{~mL}$ of round-bottomed flask was added a $40 \%$ aqueous $\mathrm{KOH}$ solution $(40 \mathrm{~mL})$. The solution was stirred at reflux for $8 \mathrm{~h}$, cooled to room temperature, and the organic solvent was removed under reduced pressure. The $\mathrm{pH}$ of the reaction mixture was set to 2 by adding $\mathrm{HCl}$ solution $(6 \mathrm{M})$, and the precipitate was formed. The precipitate was collected and washed with ample amount of water and dried. The collected solid material was suspended in chloroform $(100 \mathrm{~mL})$, and stirred at reflux for $1 \mathrm{~h}$. Filtering, and subsequent drying under reduced pressure of the solid was afforded $\mathbf{H}_{2} \mathbf{P c}$ as a dark green solid (336 mg, $6.0 \%$ overall yield for 2 steps with reference to 2 used). Mp. $>300{ }^{\circ} \mathrm{C} ;{ }^{1} \mathrm{H}$ NMR $(400 \mathrm{MHz}$, THF-d $\left.\mathrm{d}_{8}\right) \delta 10.83(\mathrm{~s}, 1 \mathrm{H}$, carboxy H), $9.18(\mathrm{~s}, 6 \mathrm{H}$, phenyl H $(2,3,9,10,16,17)), 9.15$ (s, 2H, phenyl H (23,24)), 8.08 (d, 4H, J=8.3 Hz, carboxyphenyl H), $7.63(\mathrm{~d}, 4 \mathrm{H}, J=8.3 \mathrm{~Hz}$, carboxyphenyl H), 7.49 (d, 4H, J=8.3 Hz, carboxyphenyl H), 7.43 (s, 20H, carboxyphenyl H), $1.43(\mathrm{~s}, 36 \mathrm{H}, t-\mathrm{Bu} \mathrm{H}), 1.41(\mathrm{~s}, 18 \mathrm{H}, t-\mathrm{Bu} \mathrm{H}),-1.55$ (br s, $2 \mathrm{H}$, inner H); FT-IR (KBr) $v_{\max } 3431,3296,2962,2903,1716,1698,1609,1506,1499,1446$, $1435,1395,1363,1315,1292,1269,1105,1011,925,835,764,727,719 \mathrm{~cm}^{-1}$; HRMS 
(FAB positive) $m / z$ calcd for $1547.7745\left(\mathrm{C}_{106} \mathrm{H}_{98} \mathrm{~N}_{8} \mathrm{O}_{4}\right)$, found $1547.7822(\mathrm{M}+\mathrm{H})^{+}$.

\section{2,3,9,10,16,17-Hexakis(4-t-butylphenyl)-23,24-bis(4-carboxyphenyl)phthalocyanato}

zinc (II) (ZnPc). To a solution of the previously collected dark green solid (500 $\mathrm{mg}$,

mixture of the 2,3,9,10,16,17-hexakis(4-t-butylphenyl)-23-(4-methoxycarbonylphenyl)-24-(4-pentoxycarbonylphenyl)phthalocyanine and 2,3,9,10,16,17-hexakis(4-t-butylphenyl)-23,24-bis(4-pentoxycarbonylphenyl)phthalocyanine) in 1-pentanol $(100 \mathrm{~mL})$ in a $300 \mathrm{~mL}$ of round-bottomed flask was added anhydrous zinc acetate $(500$ $\mathrm{mg}, 3.0 \mathrm{mmol})$. The solution was stirred at $130{ }^{\circ} \mathrm{C}$ for $3 \mathrm{~h}$ under nitrogen atmosphere. After cooling to room temperature, the solvent was removed under reduced pressure. Silica gel column chromatography (chloroform) of the crude product afforded a green solid (103 mg). The solid showed the two molecular ion peaks at 1692.5 and 1748.6 with the intensity ratio of 1:3 on the mass spectrometry (MALDI-TOF). Each of the peaks corresponds to $2,3,9,10,16,17$-hexakis(4-t-butylphenyl)-23-(4-methoxycarbonylphenyl)-24-(4-pentoxycarbonylphenyl)phthalocyanatozinc (II), and 2,3,9,10,16,17hexakis(4-t-butylphenyl)-23,24-bis(4-pentoxycarbonylphenyl)phthalocyanatozinc (II), respectively. The mixture was directly employed for the next reaction without further 
purification.

To a solution of the previously collected green solid $(103 \mathrm{mg})$ in THF/methanol $(2: 1(\mathrm{v} / \mathrm{v}), 30 \mathrm{~mL})$ in a $100 \mathrm{~mL}$ of round-bottomed flask was added a $40 \%$ aqueous $\mathrm{KOH}$ solution $(30 \mathrm{~mL})$. The solution was stirred at reflux for $5 \mathrm{~h}$, cooled to room temperature, and the organic solvent was removed under reduced pressure. The $\mathrm{pH}$ of the reaction mixture was set to 4 by adding $6 \mathrm{M} \mathrm{HCl}$ solution, and the precipitate was formed. The precipitate was collected and washed with ample amount of water and dried. The collected solid material was suspended in chloroform $(100 \mathrm{~mL})$, and stirred at reflux for $1 \mathrm{~h}$. Filtering, and subsequent drying under reduced pressure of the solid was afforded ZnPc as a dark green solid (52.6 mg, $4.6 \%$ overall yield for 3 steps with reference to 2 used). Mp. > $300{ }^{\circ} \mathrm{C} ;{ }^{1} \mathrm{H}$ NMR $(400 \mathrm{MHz}$, THF-d $\left.{ }_{8}\right) \delta 10.72(\mathrm{~s}, 1 \mathrm{H}$, carboxy H), 9.47 (s, 2H, phenyl H (23,24)), 9.47 (s, 2H, phenyl $\mathrm{H}(9,10)), 9.39$ (s, 4H, phenyl H $(2,3,16,17)), 7.10$ (d, 4H, J=8.3 Hz, carboxyphenyl H), 7.72 (d, 4H, J=8.3 Hz, carboxyphenyl H), 7.53 (skewed d, J=8.3 Hz, 12H, carboxyphenyl H), 7.46 (skewed d, $J=8.3 \mathrm{~Hz}, 12 \mathrm{H}$, carboxyphenyl H), 1.41 (s, 36H, $t$-Bu H), $1.40(\mathrm{~s}, 18 \mathrm{H}, t$-Bu H); HRMS (FAB positive) $m / z$ calcd for 1608.6846 
$\left(\mathrm{C}_{106} \mathrm{H}_{96} \mathrm{~N}_{8} \mathrm{O}_{4} \mathrm{Zn}\right)$, found 1608.6816 $(\mathrm{M}+\mathrm{H})^{+}$.

Density Functional Theory (DFT) Calculations. Geometry optimization and electronic structure calculations of the porphyrins were performed by using B3LYP functional and 3-21G (d) basis set implemented in the Gaussian 03 program package. ${ }^{30}$ Molecular orbitals were visualized by GaussView 3.0 software.

Preparation of Phthalocyanine-Modified $\mathrm{TiO}_{2}$ Electrode and Photovoltaic Measurements. Preparation of mesoporous $\mathrm{TiO}_{2}$ films and immobilization of the phthalocyanine on the $\mathrm{TiO}_{2}$ surface, and characterization of the photovoltaic properties of phthalocyanine-modified $\mathrm{TiO}_{2}$ were made by following the procedures reported previously. ${ }^{18}$ Tetrahydrofuran was used as an immersing solvent in the present experiments instead of ethanol or methanol. The $\mathrm{TiO}_{2}$ electrodes modified with $\mathrm{H}_{2} \mathrm{Pc}$ and $\mathrm{ZnPc}$ are denoted as $\mathrm{TiO}_{2} / \mathrm{H}_{2} \mathrm{Pc}$ and $\mathrm{TiO}_{2} / \mathrm{ZnPc}$, respectively. The amounts of the phthalocyanines adsorbed on the $\mathrm{TiO}_{2}$ films were determined by measuring the changes in the absorbance of the phthalocyanine solutions $(4 \mathrm{~mL})$ before and after immersing the $\mathrm{TiO}_{2}$ films $\left(0.25 \mathrm{~cm}^{2}\right.$ of projected area). All the experimental values were given as an average from six independent measurements. 
Acknowledgement. This work was supported by Grant-in-Aid (No. 19350068 for H.I.) from the Ministry of Education, Culture, Sports, Science and Technology (MEXT), Japan and NEDO. We gratefully acknowledge Prof. Susumu Yoshikawa (Kyoto University) and Prof. Shozo Yanagida and Dr. Naruhiko Masaki (Osaka University) for the use of the equipment for photovoltaic measurements. Computation time was provided by the Academic Center for Computing and Media Studies, Kyoto University. S. E. thanks the International Doctoral Program in Engineering, Graduate School of Engineering, Kyoto University, for financial support. 
TABLE 1: Optical and Electrochemical Data for the Phthalocyanines and Driving

Forces for Electron Transfer Processes on the $\mathrm{TiO}_{2}$

\begin{tabular}{|c|c|c|c|c|c|c|c|}
\hline & $\begin{array}{l}\lambda_{\text {abs }}^{a} \\
/ \mathrm{nm}\end{array}$ & $\begin{array}{l}\lambda_{\mathrm{em}}^{b} \\
/ \mathrm{nm}\end{array}$ & $\begin{array}{c}E_{\mathrm{ox}}{ }^{c} \\
/ \mathrm{V}\end{array}$ & $\begin{array}{l}E_{0-0}{ }^{d} \\
/ \mathrm{eV}\end{array}$ & $\begin{array}{c}E_{\mathrm{ox}}{ }^{e} \\
/ \mathrm{V}\end{array}$ & $\begin{array}{c}\Delta G_{\mathrm{inj}}^{f} \\
/ \mathrm{eV}\end{array}$ & $\begin{array}{c}\Delta G_{\mathrm{reg}}{ }^{g} \\
/ \mathrm{eV}\end{array}$ \\
\hline $\mathrm{ZnPc}$ & $\begin{array}{l}622.0 \\
691.0\end{array}$ & $\begin{array}{l}699 \\
730\end{array}$ & +0.94 & 1.78 & -0.84 & -0.34 & -0.44 \\
\hline $\mathrm{H}_{2} \mathrm{Pc}$ & $\begin{array}{l}357.9,416.3 \\
619.4,651.1 \\
681.0,714.5\end{array}$ & $\begin{array}{l}718 \\
747\end{array}$ & +1.27 & 1.73 & -0.46 & +0.04 & -0.77 \\
\hline
\end{tabular}

${ }^{a}$ Wavelengths for $\mathrm{B}$ and $\mathrm{Q}$ bands maxima in THF. ${ }^{b}$ Wavelengths for emission maxima in THF by exciting at the B band maxima. ${ }^{c}$ Ground state oxidation potentials (vs NHE). ${ }^{d}$ The zero-zero excitation estimated from the interaction of the normalized absorption and emission spectra. ${ }^{e}$ Excited-state oxidation potentials approximated from $E_{\mathrm{ox}}$ and $E_{0-0}$ (vs NHE). ${ }^{f}$ Driving forces for electron injection from the phthalocyanine excited singlet state $\left(E_{\mathrm{ox}}{ }^{*}\right)$ to the conduction band of the $\mathrm{TiO}_{2}(-0.5 \mathrm{~V}$ vs NHE). ${ }^{g}$ Driving forces for the regeneration of phthalocyanine radical cation $\left(E_{\mathrm{ox}}\right)$ by $\mathrm{I}^{-} / \mathrm{I}_{3}{ }^{-}$redox couple $(+0.5 \mathrm{~V}$ vs NHE$)$. 

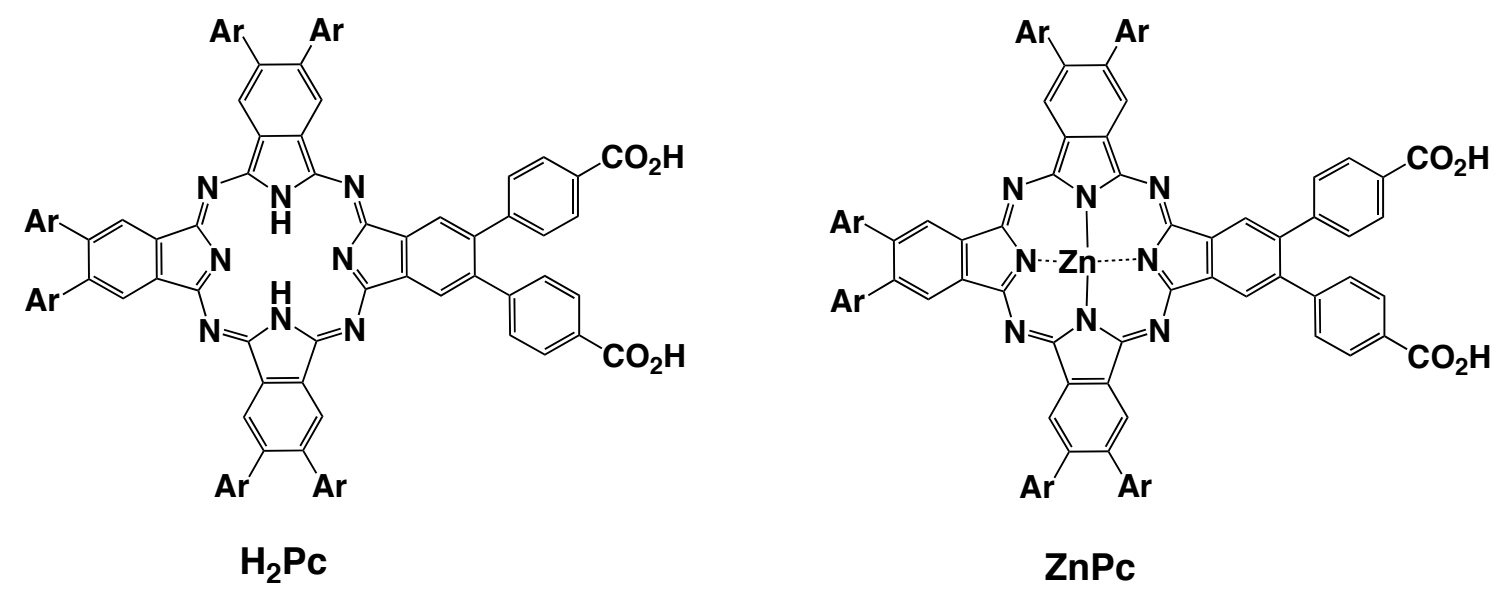

$$
\mathrm{Ar}=\xi-\mathrm{Bu}
$$

Figure 1. Structures of the phthalocyanines used in this study. 


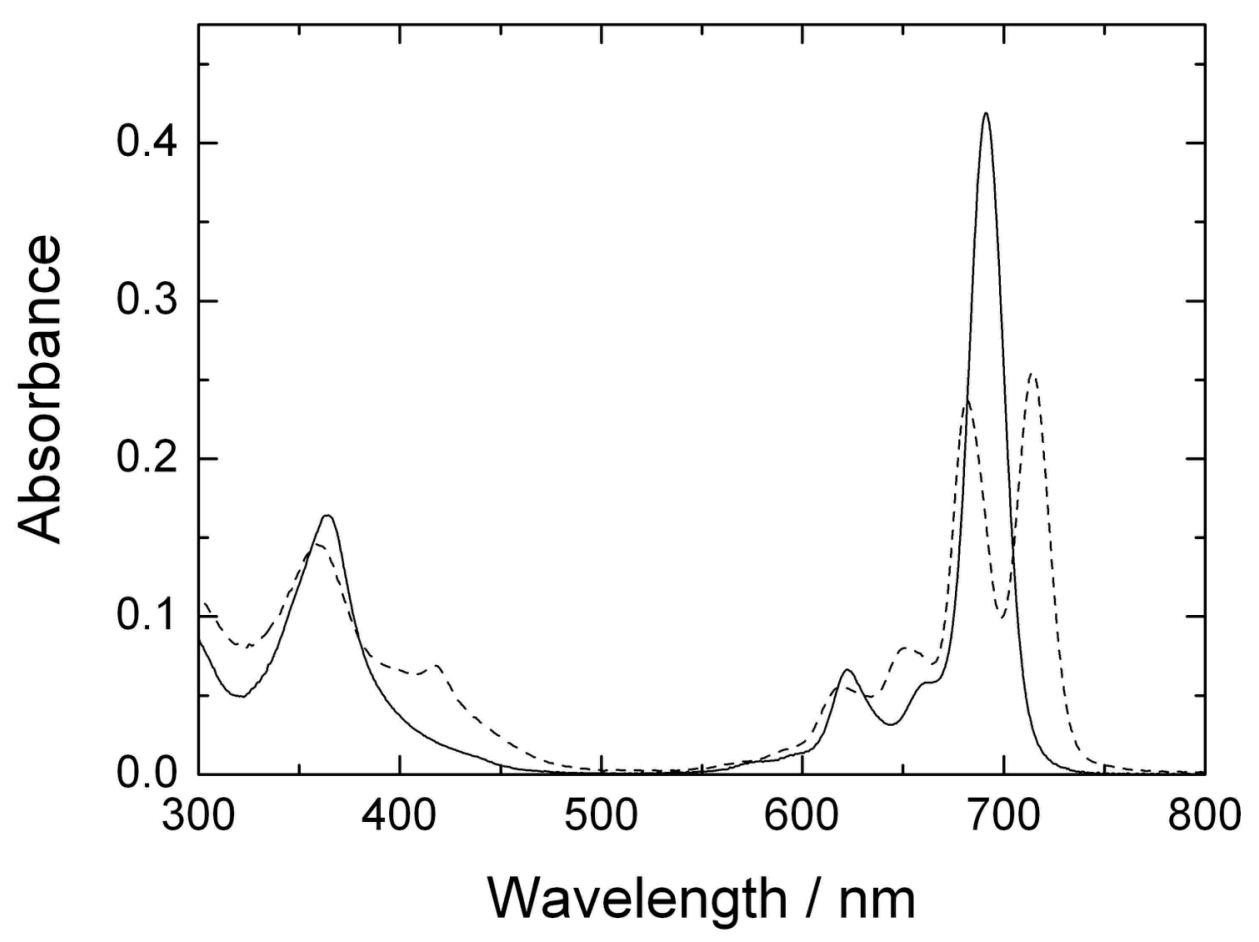

Figure 2. UV-visible absorption spectra of $\mathrm{ZnPc}$ (solid) and $\mathrm{H}_{2} \mathrm{Pc}$ (dashed) measured in $2 \times 10^{-6} \mathrm{M}$ of THF solution. Optical length $=1 \mathrm{~cm}$. 


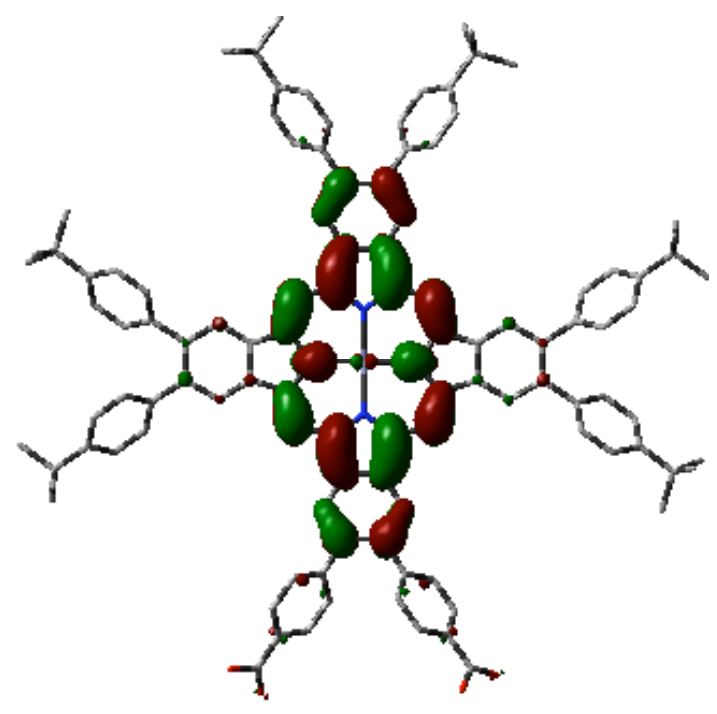

(a)

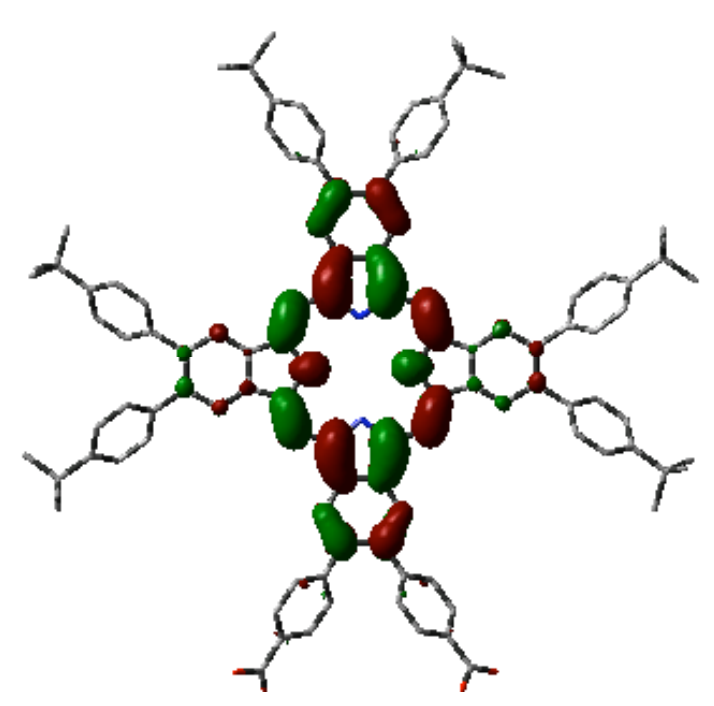

(b)

Figure 3. LUMOs of (a) $\mathrm{ZnPc}$ and (b) $\mathrm{H}_{2} \mathrm{Pc}$ calculated by DFT methods with B3LYP/3-21G(d). The protons are omitted for clarity. 


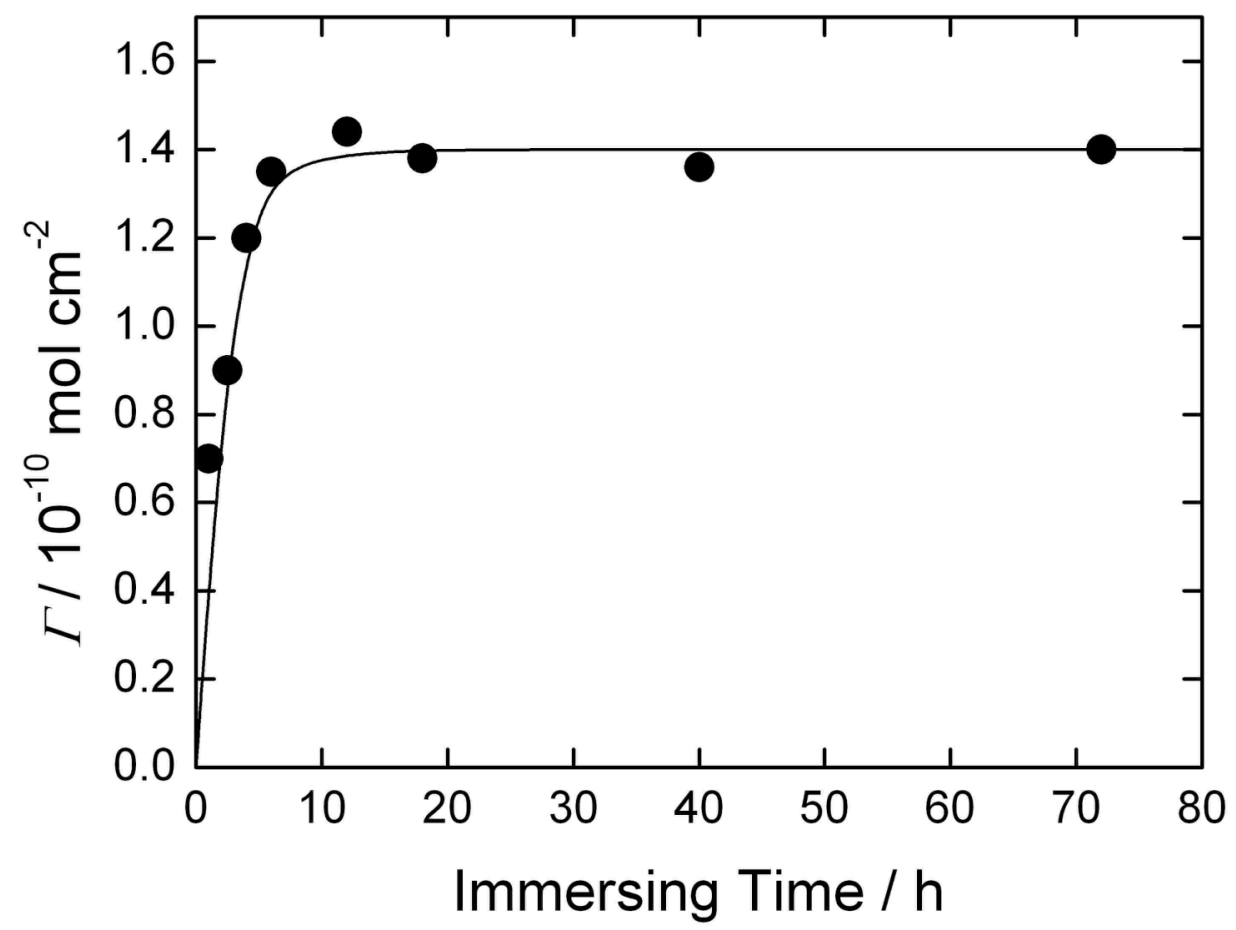

Figure 4. Profile of the surface coverage $(I)$ of $\mathrm{ZnPc}$ on the $\mathrm{TiO}_{2}$ electrode depending on the immersing time of the $\mathrm{TiO}_{2}$ electrode into the THF solution of $\mathrm{ZnPc}(0.05 \mathrm{mM})$. 


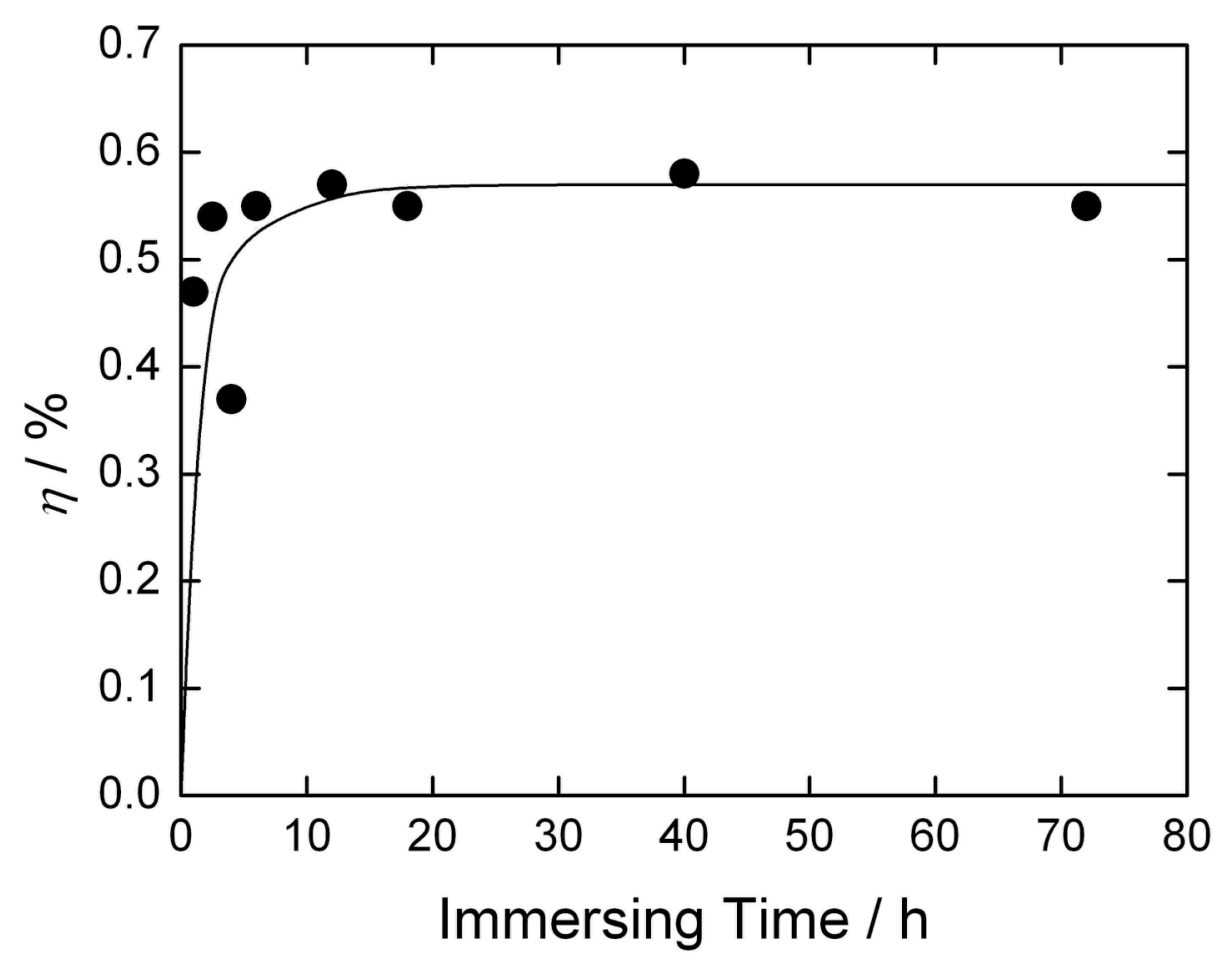

Figure 5. Profile of the power conversion efficiency $(\eta)$ of $\mathrm{ZnPc}$-sensitized $\mathrm{TiO}_{2}$ cell depending on the immersing time of the $\mathrm{TiO}_{2}$ electrode in the $\mathrm{ZnPc}-\mathrm{THF}$ solution $(0.05$ $\mathrm{mM})$. 


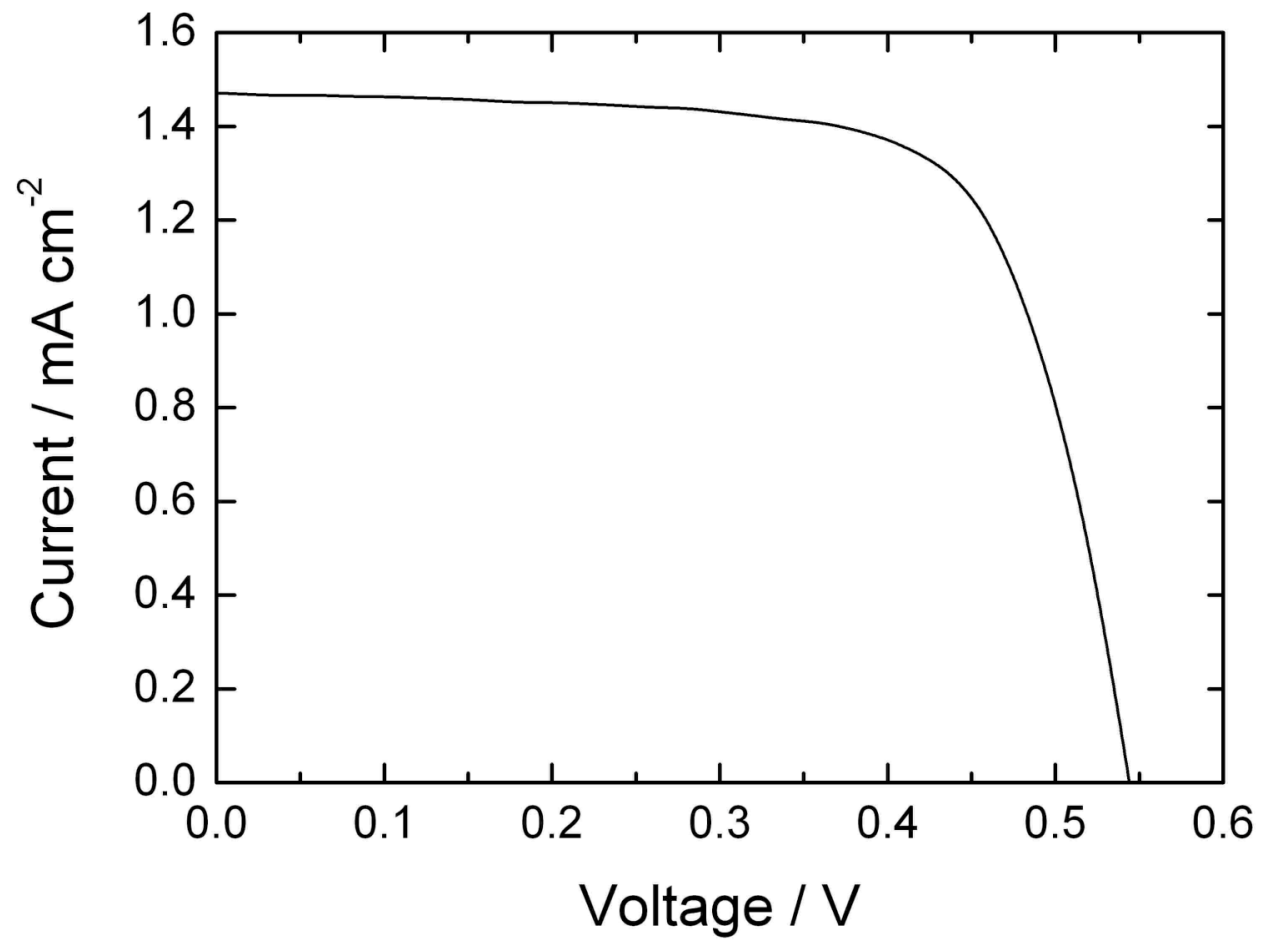

Figure 6. Photocurrent-voltage characteristics of $\mathrm{ZnPc}$-sensitized $\mathrm{TiO}_{2}$ cell $(\eta=$ $\left.0.57 \%, J_{\mathrm{sc}}=1.47 \mathrm{~mA} \mathrm{~cm}^{-2}, V_{\mathrm{oc}}=0.54 \mathrm{~V}, f f=0.71\right) . \quad$ Conditions: electrolyte $0.1 \mathrm{M} \mathrm{LiI}$, $0.05 \mathrm{M} \quad \mathrm{I}_{2}, \quad 0.6 \mathrm{M}$ 2,3-dimethyl-1-propyl imidazolium iodide, and $0.5 \mathrm{M}$ 4-t-butylpyridine in $\mathrm{CH}_{3} \mathrm{CN}$; input power: $\mathrm{AM} 1.5$ under simulated solar light $(100 \mathrm{~mW}$ $\left.\mathrm{cm}^{-2}\right) . \eta=J_{\mathrm{sc}} \times V_{\mathrm{oc}} \times f f$. 


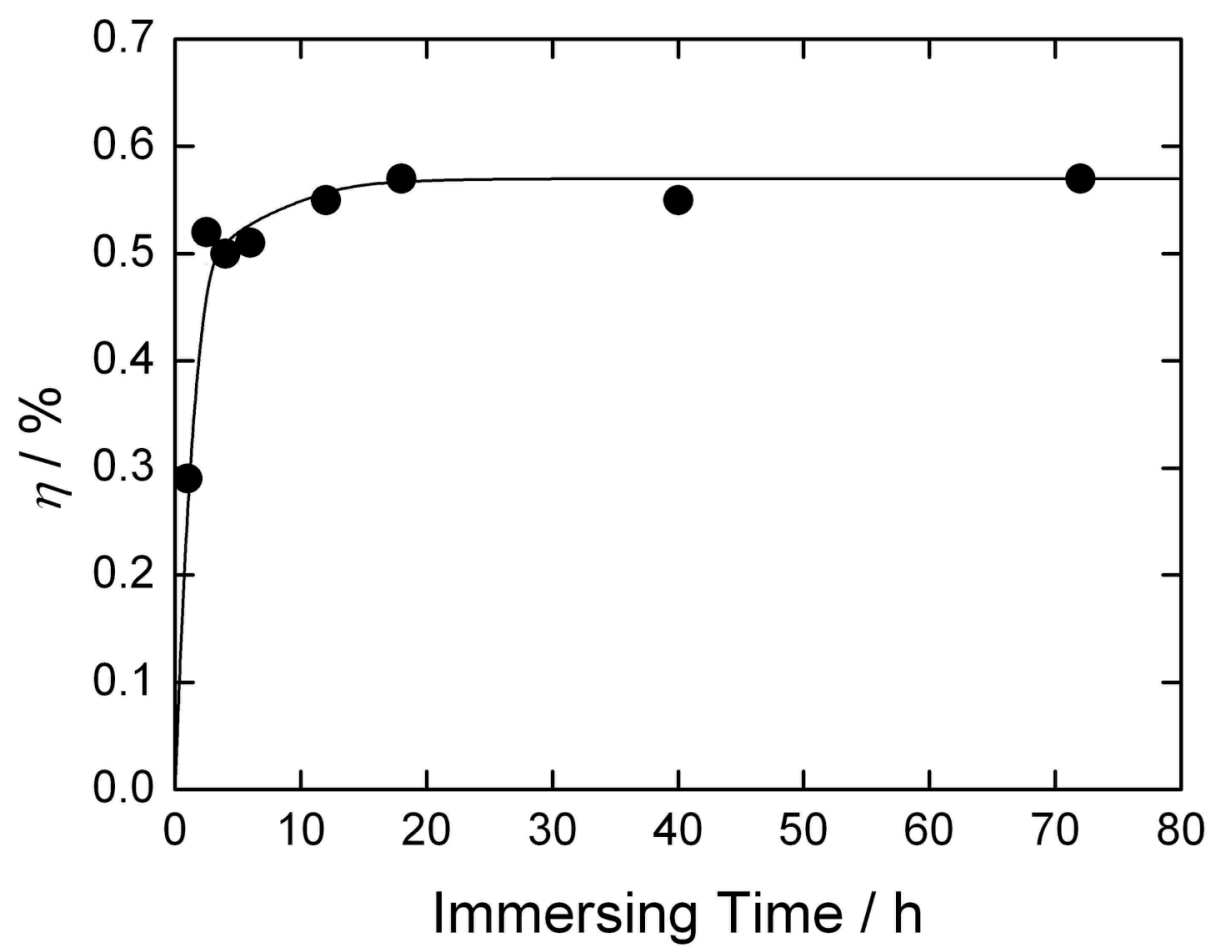

Figure 7. Profile of the power conversion efficiency $(\eta)$ of $\mathrm{ZnPc}$-sensitized $\mathrm{TiO}_{2}$ cell depending on the immersing time of the $\mathrm{TiO}_{2}$ electrode in the $\mathrm{ZnPc}-\mathrm{THF}$ solution $(0.05$ $\mathrm{mM})$ in the presence of chenodeoxycholic acid (2.5 mM). 

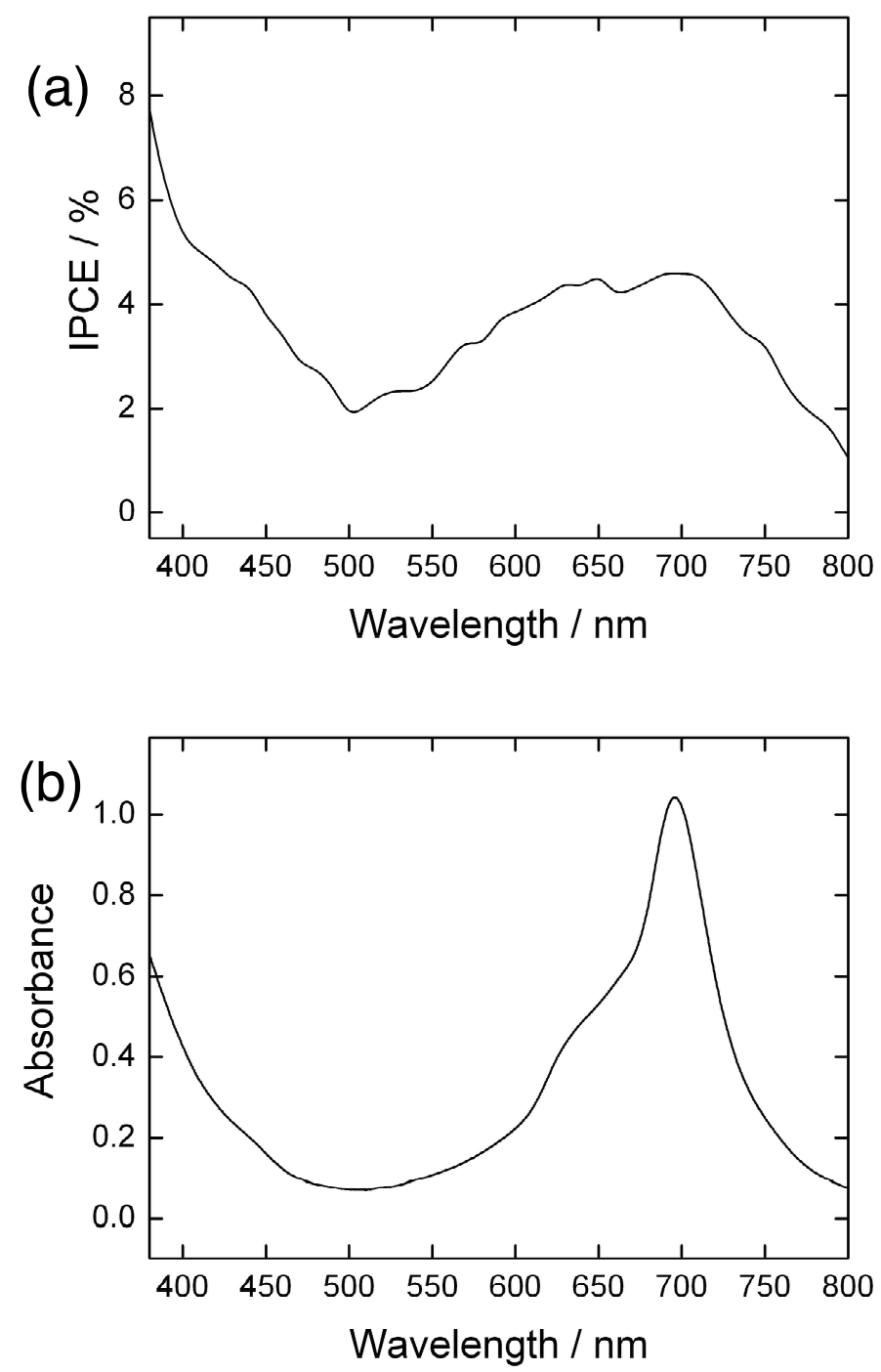

Figure 8. (a) Photocurrent action spectra of $\mathrm{ZnPc}$-sensitized $\mathrm{TiO}_{2}$ cell. The phthalocyanine-modified $\mathrm{TiO}_{2}$ electrode was prepared under the same conditions for the power conversion efficiency $(\eta)$ measurements. Conditions: electrolyte $0.1 \mathrm{M}$ LiI, $0.05 \mathrm{M} \mathrm{I}_{2}, \quad 0.6 \mathrm{M}$ 2,3-dimethyl-1-propyl imidazolium iodide, and $0.5 \mathrm{M}$ 4-t-butylpyridine in $\mathrm{CH}_{3} \mathrm{CN}$; input power: $\mathrm{AM} 1.5$ under simulated solar light (100 $\mathrm{mW}$ $\mathrm{cm}^{-2}$ ). (b) UV-visible absorption spectra of $\mathrm{TiO}_{2} / \mathrm{ZnPc}$. The thickness of the $\mathrm{TiO}_{2}$ was adjusted to be $700-1000 \mathrm{~nm}$ to obtain the shape and peak position of the spectra accurately. 


\section{Notes and references}

(1) (a) C. W. Tang, Appl. Phys. Lett. 1986, 48, 183. (b) G. Yu, J. Gao, J. C. Hummelen, F. Wudl and A. J. Heeger, Science, 1995, 270, 1789. (c) C. A. Bignozzi, R. Argazzi and C. J. Kleverlaan, Chem. Soc. Rev., 2000, 29, 87. (d) H. Imahori, J. Mater. Chem., 2007, 17, 31.

(2) B. O’Regan and M. Grätzel, Nature, 1991, 353, 737.

(3) (a) Special Issue on Dye-Sensitized Solar Cells: Coord. Chem. Rev., 2004, 248,

1161. (b) Forum on Solar and Renewable Energy: Inorg. Chem., 2005, 44, 6799. (c)

D. F. Watson and G. J. Meyer, Ann. Rev. Phys. Chem., 2005, 56, 119 . (d) N. A. Anderson and T. Lian, Ann. Rev. Phys. Chem., 2005, 56, 491. (e) W. R. Duncan and O. V. Prezhdo, Ann. Rev. Phys. Chem., 2007, 58, 143. (f) N. Robertson, Angew. Chem., Int. Ed., 2006, 45, 2338.

(4) (a) N. Robertson, Angew. Chem., Int. Ed., 2008, 47, 1012. (b) M. Tanaka, S. Hayashi, S. Eu, T. Umeyama, Y. Matano and H. Imahori, Chem. Commun., 2007, 2069.

(c) Y. Shibano, T. Umeyama, Y. Matano, and H. Imahori, Org. Lett., 2007, 9, 1971.

(5) G. de la Torre, C. G. Claessens and T. Torres, Chem. Commun., 2007, 2000.

(6) (a) Md. K. Nazeeruddin, R. Humphry-Baker, M. Grätzek, D. Wöhrle, S. Schnurpfeil, G. Schneider, A. Hirth and N. Trombach, J. Porphyrins Phthalocyanines, 1999, 3, 230. (b) V. Aranyos, J. Hjelm, A. Hagfeldt and H. Grennberg, J. Porphyrins Phthalocyanines, 2001, 5, 609. (c) J. He, A. Hagfeldt, S.-E. Lindquist, H. Grennberg, F. Korodi, L. Sun and B. Åkermark, Langmuir, 2001, 17, 2743 . (d) Y. Amao and T. Komori, Langmuir, 2003, 19, 8872. (e) E. Palomares, M. V. Martinez-Diaz, S. A. Haque, T. Torres and J. R. Durrant, Chem. Commun., 2004, 2112. (f) L. Giribabu, CH. V. Kumar, V. G. Reddy, P. Y. Reddy, Ch. S. Rao, S.-R. Jang, J.-H. Yum, Md. K. Nazeeruddin and M. Grätzel, Solar Energy Mater. Solar Cells, 2007, 91, 1611. (g) M. 
Yanagisawa, F. Korodi, J. He, L. Sun, V. Sundström and B. Åkermark, J. Porphyrins Phthalocyanines, 2002, 6, 217. (h) M. Yanagisawa, F. Korodi, J. Bergquist, A. Holmberg, A. Hagfeldt, B. Åkermark and L. Sun, J. Porphyrins Phthalocyanines, 2004, 8, 1228. (i) A. Morandeira, I. Lopez-Duarte, M. V. Martínez-Díaz, B. O’Regan, C. Shuttle, N. A. Haji-Zainulabidin, T. Torres, E. Palomares and J. R. Durrant, J. Am. Chem. Soc., 2007, 129, 9250. (j) B. O’Regan, I. Lopez-Duarte, M. V. Martínez-Díaz, A. Forneli, J. Albero, A. Morandeira, E. Palomares, T. Torres and J. R. Durrant, J. Am. Chem. Soc., 2008, 130, 2906.

(7) (a) P. Y. Reddy, L. Giribabu, C. Lyness, H. J. Snaith, C. Vijaykumar, M. Chandrasekharam, M. Lakshmikantam, J.-H. Yum, K. Kalyanasundaram, M. Grätzel and Md. K. Nazeeruddin, Angew. Chem., Int. Ed., 2007, 46, 373. (b) J.-J. Cíd, J.-H. Yum, S.-R. Jang, Md. K. Nazeeruddin, E. Martínez-Ferrero, E. Palomares, J. Ko, M. Grätzel and T. Torres, Angew. Chem., Int. Ed., 2007, 46, 8358.

(8) M. S. Rodríguez-Morgade, G. de la Torre and T. Torres, in The Porphyrin Handbook, ed. K. M. Kadish, K. M. Smith and R. Guilard, Academic Press, New York, 2000, vol. 15, ch. 99, pp. 125-160.

(9) (a) N. Miyaura and A. Suzuki, Chem. Rev., 1995, 95, 2457. (b) A. Suzuki, J. Organomet. Chem., 1999, 576, 147. (c) J-P. Corbet and G. Mignani, Chem. Rev., 2006, 106, 2651.

(10) J. Yin, M. P. Rainka, X-.X. Zhang and S. L. Buchwald, J. Am. Chem. Soc., 2002, 124, 1162.

(11) (a) A. F. Littke, C. Dai and G. C. Fu, J. Am. Chem. Soc., 2000, 122, $4020 . \quad$ (b) A. F. Littke, C. Dai and G. C. Fu, J. Am. Chem. Soc., 2002, 124, 1162 . (c) S. P. Nolan and O. Navarro, in Comprehensive Organometallic Chemistry III, ed. R. H. Crabtree and D. M. P. Mingos, Elsevier, Oxford, 2007, vol. 11, ch. 11.01, p. 7.

(12) J. Gierschner, J. Cornil and H.-J. Egelhaaf, Adv. Mater., 2007, 19, 173.

(13) The oxidation potential $\left(E_{0}\right)$ was determined by the following equation; $E_{0}=E_{\text {peak }}$ $+\Delta E / 2$, where $E_{\text {peak }}$ is the potential of peak maximum and $\Delta E$ is the pulse amplitude. A. J. Bard and L. R. Faulkner, in Electrochemical Methods-Fundamentals and Applications, John Wiley \& Sons, New York, 2nd edn., 2001, p. 290.

(14) X. Wang, Y. Zhang, X. Sun, Y. Bian, C. Ma and J. Jiang, Inorg. Chem., 2007, 46, 
7136.

(15) P. V. Kamat, M. Haria and S. Hotchandani, J. Phys. Chem. B, 2004, 108, 5166.

(16) J. B. Foresman and A. Frisch, in Exploring Chemistry with Electronic Structure Methods, Gaussian Inc., Pittsburg, PA, 2nd ed., 1995, p. 62.

(17) D. P. Hagberg, T. Edvinsson, T. Marinado, G. Boschloo, A. Hagfeldt and L. Sun, Chem. Commun., 2006, 2245.

(18) (a) H. Imahori, S. Hayashi, T. Umeyama, S. Eu, A. Oguro, S. Kang, Y. Matano, T. Shishido, S. Ngamsinlapasathian and S. Yoshikawa, Langmuir, 2006, 22, 11405. (b) S. Eu, S. Hayashi, T. Umeyama, A. Oguro, M. Kawasaki, N. Kadota, Y. Matano and H. Imahori, J. Phys. Chem. C, 2007, 111, 3528. (c) S. Eu, S. Hayashi, T. Umeyama, Y. Matano, Y. Araki and H. Imahori, J. Phys. Chem. C, 2008, 112, 4396.

(19) J. He, G. Benkö, F. Korodi, T. Polívka, R. Lomoth, B. Åkermark, L. Sun, A. Hagfeldt and V. Sundström, J. Am. Chem. Soc., 2002, 124, 4922.

(20) $\mathrm{H}_{2} \mathrm{Pc}$-sensitized $\mathrm{TiO}_{2}$ cell displayed no photocurrent response, as predicted.

(21) $\mathrm{IPCE}=\mathrm{LHE} \times \phi_{\text {inj }} \times \eta_{\mathrm{col}}$, where LHE is the light harvesting efficiency, $\phi_{\text {inj }}$ is the quantum of yield of electron injection, and $\eta_{\text {col }}$ is the efficiency of charge collection.

(22) S. A. Haque, E. Palomares, B. M. Cho, A. N. M. Green, N. Hirata, D. R. Klug and J. R. Durrant, J. Am. Chem. Soc., 2005, 127, 3456.

(23) S. N. Mori, W. Kubo, T. Kanzaki, N. Masaki, Y. Wada and S. Yanagida, J. Phys. Chem. C, 2007, 111, 3522.

(24) (a) A. N. M. Green, E. Palomares, S. A. Haque, J. M. Kroon and J. R. Durrant, J. Phys. Chem. B, 2005, 109, 12525. (b) S. A. Haque, S. Handa, K. Peter, E. Palomares, M. Thelakkat and J. R. Durrant, Ang. Chem., Int. Ed., 2005, 44, 5740.

(25) (a) B. O’Regan, J. E. Moser, M. Anderson and M. Grätzel, J. Phys. Chem, 1990, 94, 8720. (b) S. A. Haque, Y. Tachibana, D. R. Klug and J. R. Durrant, J. Phys. Chem. B, 1998, 102, $1745 . \quad$ (c) T. A. Heimer, E. J. Heilweil, C. A. Bignozzi and G. J. Meyer, J. Phys. Chem. A, 2000, 104, 4256. (d) J. N. Clifford, E. Palomares, Md. K. Nazeeruddin, M. Grätzel, J. Nelson, X. Li, N. J. Long and J. R. Durrant, J. Am. Chem. Soc., 2004, 126, 5225 .

(26) (a) G. Rothenberger, D. Fitzmaurice and M. Grätzel, J. Phys. Chem. B, 1992, 96, 5983. (b) D. F. Watson, A. Marton, A. M. Stux and G. J. Meyer, J. Phys. Chem. B, 
2003, 107, 10971. (c) D. F. Watson, A. Marton, A. M. Stux and G. J. Meyer, J. Phys. Chem. B, 2004, 108, 11680.

(27) (a) P. Wang, S. M. Zakeeruddin, J. E. Moser, R. Humphry-Baker, P. Comte, V. Aranyos, A. Hagfeldt, Md. K. Nazeeruddin and M. Grätzel, Adv. Mater., 2004, 16, 1806. (b) A. Zaban, S. Ferrere, J. Sprague and B. Gregg, J. Phys. Chem. B, 1997, 101, 55. (c) A. Zaban, S. Ferrere and B. Gregg, J. Phys. Chem. B, 1998, 102, 452.

(28) (a) M. Grätzel, Pure Appl. Chem., 2001, 73, 459. (b) Y. Tachibana, Md. K. Nazeeruddin, M. Grätzel, D. R. Klug and J. R. Durrant, Chem. Phys., 2002, 285, 127.

(29) T. Sugimori, M. Torikata, J. Nojima, S. Tominaka, K. Tobikawa, M. Handa and K. Kasuga, Inorg. Chem. Comm., 2002, 5, 1031.

(30) J. A. Pople, et al., Gaussian 03, revision C.02, Gaussian Inc., Wallingford, CT, 2004. 